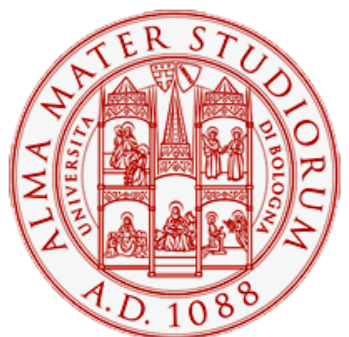

Alma Mater Studiorum - Università di Bologna DEPARTMENT OF ECONOMICS

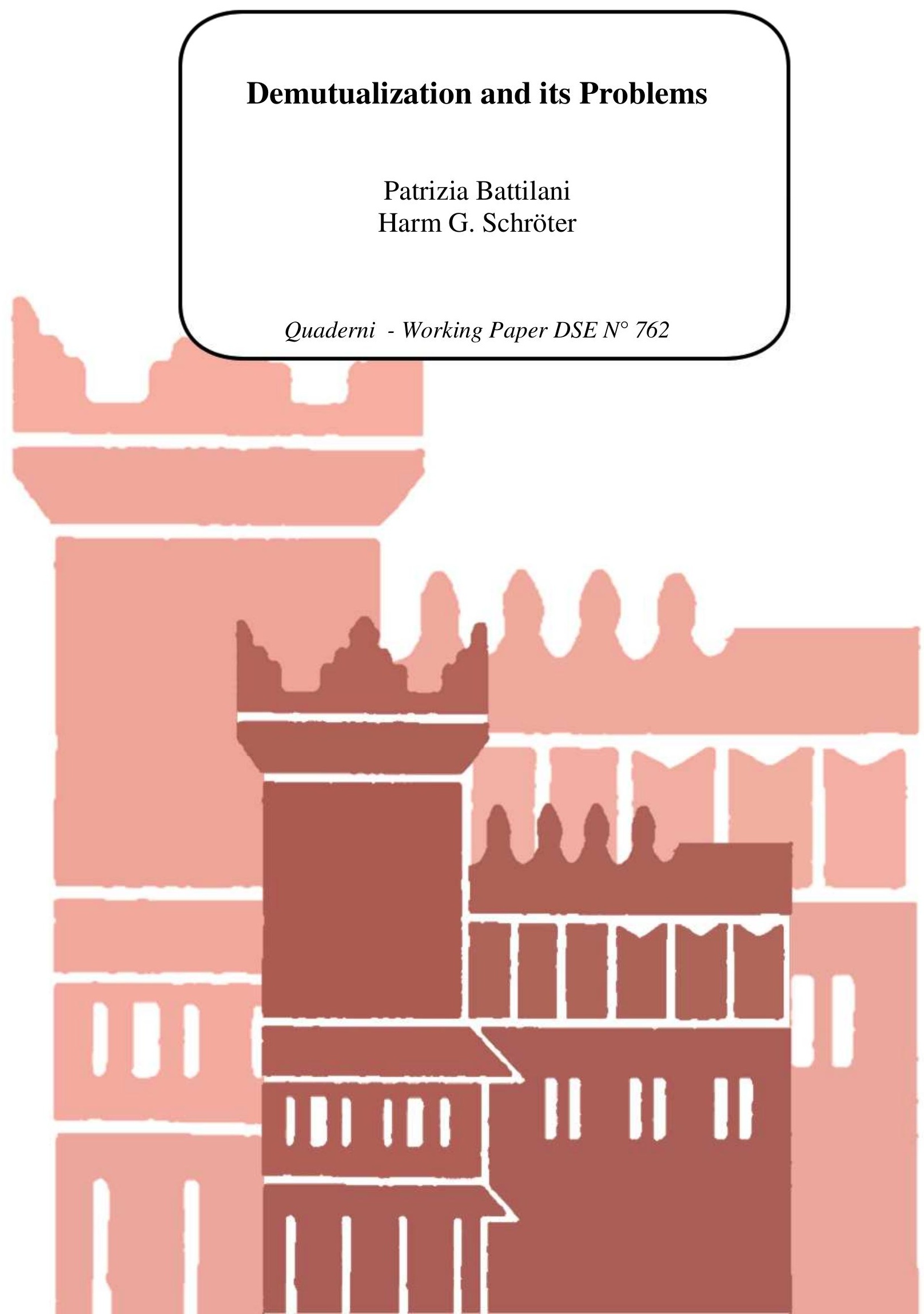




\title{
Demutualization and its Problems
}

\author{
Patrizia Battilani, Department of Economics, , University of Bologna \\ Harm G. Schröter, Department of Archaeology, History, Cultural Studies and Religion, University \\ of Bergen
}

\begin{abstract}
Over the last three decades cooperatives experienced acceleration of institutional innovation with the introduction of many variations to the reference model. It is certainly not surprising that coops changed their organizational structure over time to face the challenges of world. In the United States and in Canada they are commonly referred to as New generation cooperatives, in Italy and Spain as cooperative groups or network of cooperatives. One of the main feature of these new organizational structures is their attempt to take some advantages of the investor oriented firms (above all in capital raising activities) while retaining the mutual/cooperative status. Many of these changes have been undertaken to facilitate the growth of the enterprises both in domestic market and abroad. Due to the wideness of the phenomenon we could name the last three decades the age of hybridization. However in some cases the search for new structures went further and assumed the aspect of conversion of mutuals into stock firms. Our paper will deal with this latter part of the story, focusing on cooperatives that preferred conversion or demutualization to hybridization. The paper describes the chronology and the geography of demutualization and analyses the forces that drove it over the last decades. The main conclusion is that demutualization provided solutions for real problems, as hybridization did, however the choice between these two options seems to have been more a matter of ideology than of efficiency.
\end{abstract}

Keywords: cooperatives, demutualization, hybridization Jel classification: N80

\section{Introduction}

Over the last decades the world economy has undergone far-reaching changes which have shaped the current framework of international capitalism. Gerald Epstein summarized them in three words, neoliberalism, globalization and financialization. ${ }^{1}$ These processes deeply affected not only the firms' strategies but also their governance. All forms of enterprises facing these new challenges have changed in some way their organizational structures as well as their financial strategies. Even cooperatives tried to do it experiencing a wave of innovations such as new forms of cooperative enterprises have emerged. In the United States and in Canada they are commonly referred to as New generation cooperatives, in Italy and Spain as cooperative groups or network of cooperatives. One of the main feature of these new organizational structures is their attempt to take some advantages of the investor oriented firms (above all in capital raising activities) while retaining the mutual/cooperative status. According to some economists they can be considered an hybrid, the publicly listed cooperative (Nilsson 2001, Chaddad and Cook 2004; Bekkum, O.F. van and J. Bijman, 2006). No doubts that this innovation in structures and organizational models has been the salient feature of coops at the turn of XXI century. Many of these changes have been undertaken to

1 Gerald Epstein, Financialization and the World Economy, Edward Elgar Publishing, 2005 
facilitate the growth of the enterprises both in domestic market and abroad. As historians we are not in a position to say what is now emerging will be the cooperation of the XXI century, but certainly we could name the last three decades the age of hybridization. Besides at the end of this transformation a new paradigm with a new set of values and reference models could emerge.

However in some cases the search for new structures went further and assumed the aspect of conversion of mutuals into stock firms. Our paper will deal with this latter part of the story, focusing on cooperatives that preferred conversion or demutualization to hybridization.

Historically demutualization is primarily a problem of the time after the Second World War, or to be more precise, one of the last few decades (for definition see $\S 2$ ). It started earlier in some countries and was taken over in others later. A first thesis of ours is, that this forging ahead by some and falling behind by others, was not a process of coincidence. Fabio Chaddad observed: “...most notably Australia, Great Britain, South Africa and the USA" were engaged in this process (Chaddad 2004, 576). Alfred Chandler suggested the USA being more tuned to a competitive oriented economy than other major countries (Chandler 1990). It was in the USA where the competitive oriented "Chicago-School" of economists flourished and later was able of influencing the whole world. Also privatization and deregulation started in this country. Therefore it was not by chance that the United States acted a path-breaker also in the case of demutualization. On a broad scale the movement started in the USA, spread first to the Anglo-Saxon countries by a process called Americanization, and later influenced decision-making in all parts of the world. Only in few countries demutualization was not put on the agenda; usually where legislation placed restrictions on conversion. France as the sole opted for a different path. Indeed, in the same years in which coops demutualized worldwide, the French government mutualised the 34 regional savings banks with a new law on financial security. ${ }^{2}$ We could say that also the map of countries that did not follow the US model was not a process of coincidence.

Most persons engaged in demutualization were convinced to do the right thing, especially to ease capital constraints of the respective firm, and by doing so, enrich the old and new owners. Not so much by exploiting customers but through a better organization, an improved management, decision-making and so on. Many persons involved considered coops a more or less outdated form of enterprise. Though in 2010 demutualization can be questioned, decision-makers in the previous two decades usually had the best intentions and the best conscious when demutualizing their coop.

The aim of this essay is to address the demutualization process in an historical perspective and provide some explanations for its acceleration over the last two decades and its slowdown after the 2008 financial crisis.

Among others, four questions deserve an answer:

- Why demutualization was a worldwide process?

- What has been driving demutualization?

- Did demutualization take place in public interest?

- What is the relationship between demutualization and hybridization?

An answer to all these questions will be provided in the following paragraphs

2 Over the 1990s the 186 French Saving Banks were reorganized into 34 regional-based banks and one national bank which operated as one group (the market share was around 10\%). After this reorganization the regional savings banks were mutualised with the Law No 25 of June 1999. A pyramid scheme was set up. At the basis were 451 local savings societies which hold all the shares of the savings banks to which they were attached. Among other things, the mutualization made it possible to project the merger between the Savings bank group and the Credit Unions. So in 2006, the Banques Populaires and the Caisses d'Epargne began the process with the creation of their joint subsidiary, Natixis and in 2009 the two groups merged their central institutions, giving birth to the second largest French banking group. 
2. Why demutualization was a worldwide process?

\section{A. A problem of definition}

Before addressing these issues is important to provide a definition of demutualization, because it has been defined in at least three different ways. The first one that dates back to nineties and has been clearly restated by Chaddad and Cook in 2004 and 2007:

it is a change in the ownership structure of user owned and controlled organizations from a mutual to a for-profit, proprietary organization. As a result of demutualization, residual claim and control rights are reassigned among stakeholders with implications to firm behaviour and performance. In particular, cooperative membership rights are converted to unrestricted common stock ownership rights in a corporate organization...

Following this definition the mergers of coops in order to create a new one, the purchases of companies by coops, the creation of companies owned by cooperatives, the creation of a cooperative group are not examples of demutualization. That means that the deep changes in structure and organization experienced by many cooperative movements over the last thirty years all over the world cannot be considered a sort of demutualization. Instead they are to be classified as institutional innovation aimed to face increasing competition and globalization.

Very clear as well as very deep is the difference between the definition described above and the following offered by Zvi Galor in 2007 which is summarised in figure 1. According to this scholar the great part of new form of cooperatives like the NGC in USA and Canada or the Cooperative

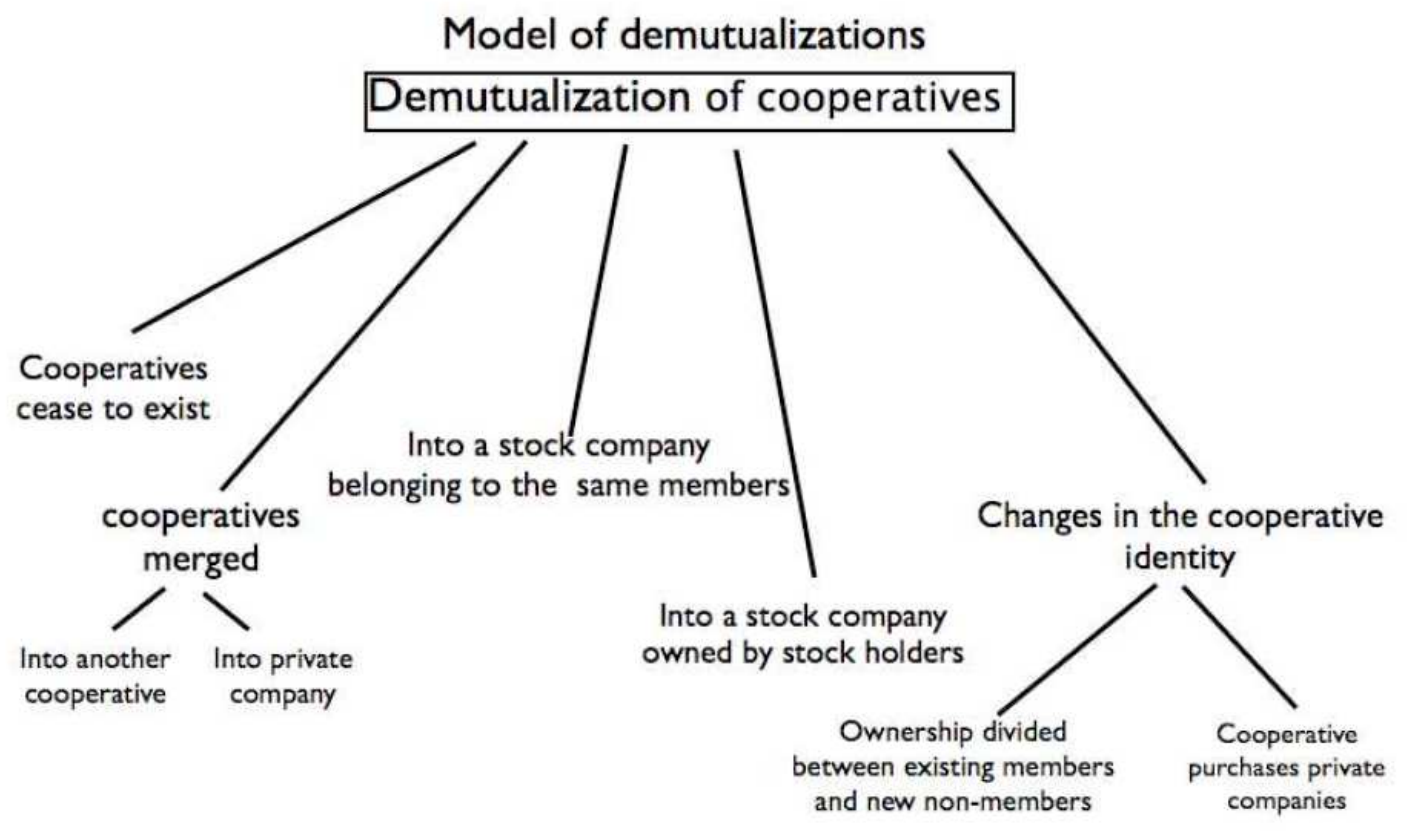

group in Italy risk to be classified as examples of demutualization.

In other words the definition of demutualization is intimately connected with the debate on traditional versus new coops. We will come back to the issue later.

A partially different view is that taken by Griffiths 2004 who claims that "the origin of demutualization is when the cooperative has lost its cooperative identity and what distinguishes it from investor-oriented companies." In other words he identified two stages of demutualization: a 
first-one in which cooperatives loose their values and the second one, characterised by the formal conversion in investor oriented enterprises. This view was shared also by the ICA president of that time, Ivano Barberini, a former manager of the Italian consumer cooperation, who in 2007 claimed:

"The economic value of cooperation is the result of the implementation of its social values for the benefit of members and of the community in which the cooperatives operate. Nevertheless, on occasion this has not been the case, and changes have taken a direction that is anything but the right one. In diverse parts of the world, certain major cooperative groups have favoured the logic of pure financial gain and market dynamics, to the detriment of the characteristic identity of cooperation. In certain situations, decisions of this kind have led to the complete "demutualization" of cooperative enterprises."(Barberini 2007)

To sum up we can say that at least three kind of definitions of demutualization has been used by scholars and practitioners: the first one focusing on ownership structure (Chaddad 2004 and Birchall 1998), the second taking into consideration the deviation from traditional cooperatives (Zvi Galor 2007) and the third one based on the coop values (Griffith 2004 and Barberini 2007).

To end this part it is worth remembering the point of view of the private sector, quoting the demutualization definition proposed by the financial dictionary of the Australia and New Zealand Banking Group Limited: Demutualization is "the process of changing a mutual or cooperative association into a public company by converting the interests of members into shareholdings, which can then be traded through a stock exchange. Examples of mutuals in Australia are building societies, credit unions and some large insurance institutions. Their structure limits their activities to servicing their members and inhibits their ability to pursue profits and diversification as freely as companies."(www.anz.com)

As you can see this view not only defines, but also explains why demutualization happens. The definition permits us to understand how demutualization has been considered by the private sector, at least in one of the countries that led the way. It also offers a different explanation based on the rhetoric of efficiency and competition.

\section{B) Phases of demutualization}

Conversion of coops or mutuals into investor oriented enterprises and vice versa dates back to the origin of the cooperative movement ${ }^{3}$ (Mayers and Smith 1986; Carson J.M., Forster M.D. and McNamara, M.J., 1998; De Bonis, Manzone and Trento 1994). Nevertheless it is possible to identify decades in which demutualization trends spread as well as periods characterised by an opposite trend.

Unfortunately there is a considerable lack of data on demutualization. The issue has been researched only for the USA. Fitzgerald listed 105 cases up to 1968, counted from 1900 or even earlier. Covering 1968-1987 he listed another 40 cases, however without providing the exact years in all cases. From this information and from table 1 we can gather two impressions. First demutualization took place in the USA during all the time, and second their numbers went up during the last decades. Though we have no special information we can presume that the phenomenon was not unknown to European or other countries. However, the lack of interest in such a move in other countries may be a hint that it was not of particular significance elsewhere. However, demutualization became a significant issue during the last two decades. Though further investigation is needed, available data suggest for both, the USA and Europe that since the late 1980s demutualization has entered a new phase, characterized by a substantial intensification. There is also indication of its spread to South Africa and Japan until the outbreak of financial crisis in 2008. According to economic branches demutualization was unevenly spread involving especially insurance/banking as well as agricultural cooperatives and occasionally other sectors. The largest wave of demutualization, involving more than 100 million persons, was, of course, the dismantling of agricultural coops in the socialist world. Also this took place mainly during the 1990s (though in 
some cases it is still not carried out yet), its timing is another proof for the thesis of a new phase since about two decades.

Table 1. The conversion of mutuals in investor oriented firms in USA, 1900-2000

\begin{tabular}{|c|c|c|c|c|}
\hline Years & $\begin{array}{l}\text { Carson-Foster- } \\
\text { McNamara 1998 } \\
\text { data (life insurers) }\end{array}$ & \begin{tabular}{lr|} 
John & F. \\
Fitzgerald & 1987 \\
data (insurance \\
companies)
\end{tabular} & \begin{tabular}{llr}
\multicolumn{2}{l}{ Viswanathan } & and \\
Cummins 2003 & data \\
(propriety liability, & life \\
health insurers) & \\
\end{tabular} & $\begin{array}{ll}\text { Mayers and Smith } 2002 \\
\text { data } & \text { (propriety-casualty } \\
\text { company insurance) }\end{array}$ \\
\hline 1900-1910 & 5 & & & \\
\hline 1911-1920 & 2 & & & \\
\hline 1921-1930 & 8 & & & 12 \\
\hline 1931-1940 & 2 & & & 3 \\
\hline 1941-1950 & 3 & & & 9 \\
\hline 1951-1960 & 2 & & & 7 \\
\hline 1961-1970 & 3 & 5 & & 29 \\
\hline 1971-1980 & 3 & 10 & & 14 \\
\hline 1981-1990 & - & 3 & 21 & 22 \\
\hline $1991-2000$ & - & & 51 & - \\
\hline
\end{tabular}

Source: Viswanathan, K. S., and J. D. Cummins, 2003, Ownership Structure Changes in the Insurance Industry: An Analysis of Demutualization, Journal of Risk and Insurance, 70: 401-432; Mayers, D., and C. W. Smith, 2002; Ownership Structure and Control: Property-Casualty Insurer Conversions to Stock Charter, Journal of Financial Services Research,21: 117-144; Carson J.M., Forster M.D. and McNamara, M.J., 1998, 'Changes in ownership structure: theory and evidence from life-insurer demutualizations', Journal of Insurance Issues, 21, 1-22; Fitzgerald, John F., Demutualization case studies: a 20 years history, in: Journal of insurance regulation, Vol. 9, No. 2, Dec. 1990, pp. 287-310.

Table 2 Demutualization in some countries during 1980-2010

\begin{tabular}{|c|c|c|}
\hline Country & First demutualization & Other demutualization \\
\hline United Kingdom & $\begin{array}{l}1989 \text { Abbey National (building } \\
\text { society) }\end{array}$ & $\begin{array}{l}\text { 1995-1999: } 18 \text { building societies and } 4 \\
\text { farmer coops }\end{array}$ \\
\hline Australia & $\begin{array}{l}\text { 1970s generalized phenomenon } \\
\text { (farmer's coops) }\end{array}$ & $\begin{array}{l}\text { 1990-1999: } 10 \text { building societies and } \\
60 \text { general cooperatives (agriculture, } \\
\text { taxi, stock exchange) }\end{array}$ \\
\hline Canada & 1999 & \\
\hline South Africa & 1998 Sanlam (mutual life insurance) & \\
\hline Japan & 2000 Daido Life (life insurance) & 2000-2010: 39 life insurance \\
\hline Former socialist countries & 1990s agricultural coops & \\
\hline
\end{tabular}

Source: Cummins and Venard 2007, Cronan 1995 and 1999; Birchall 1998; Reserve Bank of Australia, Bulletin January 1999

At the turn of the $21^{\text {st }}$ century, after many years of demutualization especially in the insurance sector in USA, UK and Australia, the phenomenon started to spread also in other countries like Canada, South Africa, Japan, Ireland, and so on. Even if conversions seemed to be restricted to two sectors, agriculture and finance, nevertheless the international cooperative movement started to be more and more worried. ICA organized a web page on this issue and in 2007 made a call for creating a committee of scholars for deeper investigation.

It was only with the outbreak of the financial crisis in 2008 that interest on demutualization came 
to and end. Above all the financial crisis put on the agenda new issues. In some country like UK the failures of demutualized societies, namely Northern Rock and Bradford \& Bingley, led consumers to transfer their business back to the mutual holding societies. In other words a new interest on mutualization emerged. However, in other countries the demutualizing process went on. Last April the Japanese Dai-ichi Life converted into an investor oriented company. Anyway until now the other three major Japanese life insurance companies have not showed any interest to demutualize into stock companies.

In the last phase of demutualization an even a reversing tendency started: re-mutualization. In September 2009 Building Societies Association published a report from The Oxford Centre for Mutual \& Employee-owned Business Kellogg College titled Converting failed financial institutions into mutual organizations. On this occasion the very innovative proposal was launched: the conversion of Northern Rock into a mutual. Why was this proposal so innovative? Northern Rock was a cooperative British building society which was converted into a company in 1992. During the financial crisis government saved it from bankruptcy and later turned it into public ownership again. According to the report, re-mutualization should be considered a way to dispose of Northern Rock (and of state-owned enterprises in general), quite a new sort of privatization.

The main goal of Northern Rock's conversion was to repay taxpayers, strengthen competition in the financial market, and create a more diversified financial sector by the diffusion of low risk enterprises like mutuals (All-Party Parliamentary Group for Building Societies and Financial Mutuals 2006).

It is not an issue of historians to predict a reversal of the de-mutualization-trend, but we think it is important to witness the emergence of this new attitude to mutuals and cooperatives. It is also important that demutualization is no longer perceived to be a one-way road. Re-mutualization of a previously demutualized coop is an option since then.

Still one issue remains unexplained: why was demutualization first wide-spread in the USA and the Anglo-Saxon world and only later spread in a larger scale to other countries? Here the concept of Americanization may help: Demutualization fitted very well into the basic concept of American competitive capitalism (Chandler 1990), thus it is no surprise that it mushroomed especially in the USA during the last decades. At the same time this is exactly the period of the third wave of Americanization in the economy (Schröter 2005). Globalization took on the form of Americanization. During this phase enterprises from abroad looked to the USA for new and improved forms above all in the fields of finance, organization and government. However, with the 2008-collaps this model has lost its attraction; a fact which surely has repercussions on the question of demutualization.

\section{What drove demutualization?}

Many reasons have been advanced to explain the demutualization process of the last decades. We can collect them into five groups. Except the fifth, all approaches can boast of a long standing tradition in economic and sociological literature. We will deal with all, one after the other.

1) Organizational isomorphism. According to this approach conversion in investor oriented enterprises would be the final stage of a non congruent isomorphic trend aimed to get legitimacy from society, from market or from financial institutions. (Hawley 1968, Meyer 1979 and Fennell 1980).

2) Cultural reasons. The same cultural environment that supported privatization from the 1980s onwards created a sympathetic attitude to the process of demutualization. (Birchall 1998).

3) Expropriation by managers (Hind 1997; Mayers and Smith 1986)

4) Political reasons. The dismantling of the socialist system in Europe entailed a wide-spread 
demutualization, simply because people perceived cooperatives as part of socialism and wanted to do away with it. During the anti-socialist wave which swept through the respective countries during the 1990s people in many quarters thought demutualization to be in public interest in order to liquidate possible pockets of socialist resistance (Wegren 2009, Ameline 2002).

5) Inefficiency or lack of growth perspectives. The starting point of this approach is the conviction that for some reasons (vaguely defined property rights, financial constraints, limited horizon of cooperative members) cooperative structure limits or even inhibits growth and viability of enterprise (Schrader 1989, Collins 1991; Fulton 1995, Cook 1995, Holmström 1999).

C.1 Isomorphism: The convergence of the organizational forms, not only of enterprises but also of political and social institutions, is the main concern of the isomorphic approach. In 1968 Hawley's defined isomorphism as a process that forces one unit in a population to resemble other units that face the same set of environmental conditions. As a consequence of this attitude the organizational structure would stepwise modify in the direction of increasing comparability with environmental characteristics. Since his pioneer paper a lot of research was undertaken to identify forces behind the isomorphic processes. A decade later Meyer (1979) and Fennell (1980) identified two types of isomorphism: competitive and institutional. According to the former the need for efficiency and competition would be the driving force of the organizational innovation and would explain the growing homogeneity of organizations. This is the view usually taken by economists, even those following the property right approach. However "highly structured organizational fields provide a context in which individual efforts to deal rationally with uncertainty and constraint often lead, in the aggregate, to homogeneity in structure, culture, and output" (Di Maggio and Powel 1983, p. 147). In other words organizations compete not just for resources and customers, but for political power and institutional legitimacy, because the latter can be the way for social as well as economic success. Thus, institutional isomorphism that can proceed without increasing internal organizational efficiency.

Further deepening by Paul J. Di Maggio and Walter W. Powell permitted to identify three mechanisms by which institutional isomorphic change occurs: coercive, mimetic and normative.

Coercive isomorphism results from the enforcement of laws and regulations or from the compulsory adoption of standard operating procedures. Mimetic isomorphism occurs in absence of any coercive authority, but when uncertainty and the lack of appropriate human capital suggest imitation as the most viable solution. The last one, normative isomorphism, is driven by the formal education in institutions, both general and vocational, the networks of professionals and the filtering of personnel.

Even if similarity can make it easier for organization to transact with each other, to attract staff with a better curriculum, to be acknowledged as legitimate and reputable, nothing can insure that these characteristics create conformist organizations more efficient than their deviant peers. This conclusion explains us why institutional isomorphism is so different from the competitive one.

The isomorphic approach has been applied to cooperative studies since the beginning of the 1990s. The first important contribution came from Bager in 1994. By using population ecology he tried to explain why cooperatives may gradually lose their identity. Bager distinguishes between "congruent isomorphism as the one which homogenizes the population (or subpopulation) of cooperatives and non-congruent isomorphism which homogenizes cooperatives with noncooperatives" (1994:43). In his view cooperatives constitute one group of population of formal organizations within an economy and an industry. During the movement's initial decades, the number of cooperatives was so large that they formed a tightly connected group, and hence there was "congruent isomorphism". During the last decades, technological and economic transformations drove cooperatives to imitate the practices of private-owned enterprise, therefore non-congruent isomorphism has become dominant. To sum up when tempting to improve their competitiveness by assimilating routines or even strategies of successful private owned enterprises, cooperatives take the risk of losing their identity. In other words in an international economy which 
strongly focuses on capital, we can expect conversion of cooperatives into private owned enterprises.

Over the last twenty years many researchers have connected the organizational transformation of coops to the institutional isomorphism, above all of the mimetic and normative kind. The increasing competition and globalization as well as the several institutional changes that characterised the last decades would have been creating an external environment dominated by uncertainty. Several cooperatives all over the world answered to this new challenge by copying private enterprises procedure and strategies. A new generation of managers, sometime coming from private enterprises, but always with a formal education, stimulated the adoption of more market oriented operating routines and procedures, while toning down solidarity values (Battilani 2009 and Battilani and Bertagnoni 2010). Finally the emerging of large scale cooperatives re-shaped the relationship between members and managers, strengthening the role of the latter (Cazzuffi and Hunt 2009).

Given for granted that isomorphism can explain institutional change that characterised coops over the last decades, the question if it also can explain demutualization does not find a final answer. Above all because demutualization remained restricted to some sectors and countries, whereas the convergence between coops and investor owned enterprises seems to be a more general trend. So it remains for scholars to explain why in some countries isomorphism reached its highest stage by conversion but not in all; or in other words, why in some sectors or in some countries social or economic legitimacy apparently required demutualization while in others it did not.

C.2 Cultural reasons: Strictly connected to institutional isomorphism is a cultural hypothesis, according to which demutualization would be a sort of by-product of privatization of public-owned enterprise. In analysing the UK experience, Birchall claimed 1998 that the same cultural values and beliefs supporting privatization asked for the demutualization of coops. So when privatization came to an end, demutualization began. At the time many scholars and professionals in the media predicted mutual organizations to be soon extinct, because ownership structure of mutuals is too inflexible for a rapidly changing financial world.

Trying to apply this model to the Australian case, in 1999 Garry Cronan came to the conclusion that even if in that country the conversion trend coexists with privatization, rather the latter followed the former. In any case, several arguments in support of privatization have been used in support of demutualization too. Connecting the cultural transformation that accompanied and supported privatization with the institutional isomorphism, we could conclude that demutualization occurred where the new ideas of increased competition spread both quick and deeply.

C.3 Expropriation by managers: The focus on management permits us to introduce the expropriation hypothesis. It contends that demutualization may be motivated by the chance of transferring wealth to management at the expense of members. The starting point is the entrance of a new generation of managers with formal education, very similar to the one received by the executives of the investor oriented enterprises. Combining these changes with the principle-agent theory some scholars drove the attention to the conflict between managers and members. Mayers and Smith (1986) analysing the conversion (in this case a mutualization) of the USA insurers suggested that wealth expropriation provides a possible explanation for conversion and identified a number of potential wealth-transfers that could occur in both direction: from members to managers and vice versa. However, in 1969 Hetherington had already suggested this kind of interpretation claiming that demutualization could be motivated by the self-interest of managers. Finally, Hind claimed in 1999 that in the later stages of the life cycle, agricultural cooperatives, now being larger and more market oriented, were stimulated to realize the aspirations of the managers, rather than those of the farmers. In 2003 Tayler in his research on the demutualization of UK building societies, concluded that in many cases management played an active role in demutualizing their societies. Based on this evidence, he suggested demutualization to be inevitable when management does not defend mutuality. 
Cook et al (2001) gave several examples of senior managers of financial mutuals making large short term financial gains as a result of a demutualization, including payouts, increased salaries in the new enterprise and a disproportionate number of shares that had been set aside for the managers and directors from those issued to the members. Stephens (2001) cites several examples where demutualizations have created huge wealth for directors and limited benefit for the members (especially those members who at the time of the demutualization were unable to afford their entitlement of shares and effectively received nothing).

There are indeed several cases were management, by pursuing its own interest, led coops into demutualization. One is the famous case of Abbey National Building Society; famous because it was the first (1989) as well as one of the largest of UK demutualizations in this sector. ${ }^{4}$ A large part of its membership actively fought management over this question. Afterwards a court ruled against the proceedings of management, but it was too late (Perks 1991, 487). Intended fraud was carried out by five directors of Madison Mutual Fire Insurance Company already in 1951. The demutualized, enriched themselves and let the new company go bust. Because there was no law against it, they went away with it! (Fitzgerald 1990) The impact of another fraud was much larger: Neue Heimat, at its time the largest building society in Europe, owning more than 300,000 flats and houses, was forced to demutualize in 1986, because top management had enriched itself on the expense of the cooperative.

\section{C.4 Political reasons.}

If we think of people, the most important wave of demutualization took place in the former socialist countries. Though hardly taken into account in western publications dealing with research on coops, this wave affected more than 100 million people. Of course, it can be argued that the coops in socialism were not "real" coops, but at least they had the potential for it. In fact great efforts were made from various western institutions in introducing western style coops. Why did these attempts fail to a large extent, why did coops in Central and Eastern Europe (CEE) demutualize?

Prior to 1990 only $4 \%$ of cultivated land was private farmland in the CEE countries. Except Poland, Rumania and parts of Slovakia coops and state-farms dominated (Millns, 4). To the agricultural coops others have to be added, for fishing, forestry as well as on all sorts of craft. Theoretically such structures were better prepared for transition to capitalism than the rest of the economy. Also politicians should have been interested, because self-aid (and learning it) is a necessary means to construct a middle-class, without which a market economy cannot survive (Steding \& Kramer, 16, 86). But demutualization took place: the number of coops fell sharply. This was due to two factors: Governments wanted to reintegrate agriculture into mainstream western market development and thought privatization to be the best way to do so. Farmers themselves were extremely sceptical towards coops, they could not imagine their functioning in a different than the traditional way without democracy: "attitude studies across the region in the mid 1990s showed that almost $60 \%$ of farmers saw voluntary cooperation as an unnecessary variant of former socialist structures" (FAO 2006, 10). In spite of massive attempts by International Cooperative Alliance (ICA) and International Labour Organization (ILO) to teach farmers otherwise, they preferred to split up the land. Even attempts with substantial transfer of know-how and human power like in Kosovo failed, because farmers co-notated coops with socialism (Egger \& Tomanek).

There are, however, variations. Privatization lead to tiny private plots, for instance 1.3 hectares in Albania or 1.6 ha in Moldova (FAO 2006, 4). In many cases the owners leased such plots to others who formed large or very large agrarian firms. In Russia the situation is - still after 20 years of transition - unclear and complicated. Officially privatization was carried through, but property

4 The second reason is a curiosity: Abbey headquarters was set up in 219-229 Baker Street, London. This comprehended 221 B Baker Street, the fictive home of Sherlock Holmes. Abbey used to answer letters addressed to him! 
rights remained unclear until today (2011). The number of private farms increased tremendously, from only 4,400 in 1991 to 267,000 in 2007, but the quantity of land only doubled (from 3.2 to 7.0 Million ha - Wegren 2009, 21). Their share of all land was only 0.4 per cent in 2008 . Today many forms of agrarian enterprise exist in Russia with undefined and varying characteristics between coops and private farms. However, those who are organized as a western-style coop, including democracy, responsibility of management, and defined ownership, probably are very few - in fact we have no information on their existence. Persons in all quarters agree that demutualization did not generally achieve its goals (Amelina 2002). Some countries took a different path, however. Slovakia and Eastern Germany (former: GDR) provide an exception to the large past-socialist demutualization-wave. There most of the land stayed with coops, which transformed themselves into western-style ones. These large enterprises, using between 1,000 and 6,000 hectares, today are highly competitive. They avoided demutualization and became profitable.

\section{C.5 Inefficiency or lack of growth perspectives:}

All previous approaches are united by the consideration that the key driver of demutualization is not the search for a more efficient organization. However the efficiency hypothesis has been tested more than any other, especially in the sector of insurance. The rational behind this hypothesis is that insurers change their organizational structure in an effort to improve financial and operational performance given the costs and benefits inherent in each type of organizational structure.

During the seventies and the eighties many of cross-sectional studies of mutual and stock financial institutions pointed out the inefficiency of the mutual enterprises. For example, Spiller (1972) and Verbrugge and Goldstein (1981) showed that the rate of asset growth was higher for stock organizations than for mutual organizations, and Frech (1980) and O'Hara (1981) found that mutual organizations had higher expenses than stock organizations.

Two sources of inefficiency have been usually recognized. The first one is capital constraints that inhibit growth and the possibility to develop new products or to expand into new geographical markets. John F. Fitzgerald (1990, 297) suggested: "Demutualization is the only practible way for raising additional capital." Viswanathan, K. S., and J. D. Cummins (2003), analysing 72 conversions that occurred during 1981-1999, concluded their research by writing: "converting firms form a unique subset of mutuals that require additional capital to sustain their current activities." However, it is worth noticing that also various forms of hybridization obtained the same result without giving up the cooperative status.

The second feature penalizing mutuals in respect to stock companies would be the absence or an inferior control of managers. The rationale behind this claim is that various control mechanisms are present for stock-owned firms but not in their mutual counterparts. Oliver Hart and John More (1996) demonstrated that cooperative ownership is prone to inefficiencies.

Therefore in the initial years of the demutualization wave, many economists advocated demutualization, especially for financial institutions. For the same reason, to compare efficiency before and after demutualization has been the main purpose of several papers published between 1986 and 2007. Nilsson Kihlén and Norell 2009 gather the most important of them in the following figure: 
Table 1. A selection of theoretical approaches to explain why large and complex traditional cooperatives may face problems.

\begin{tabular}{|c|c|c|c|}
\hline Author & Core concept & Driving forces & Ends \\
\hline $\begin{array}{l}\text { Cook, } \\
1995\end{array}$ & $\begin{array}{l}\text { Vaguely defined } \\
\text { property rights }\end{array}$ & $\begin{array}{l}\text { Large size of operations is necessary but } \\
\text { then members will free-ride, become } \\
\text { uminterested, etc. }\end{array}$ & $\begin{array}{l}\text { Exit, conversions to IOFs, } \\
\text { or reorientation to } \\
\text { individualized structures }\end{array}$ \\
\hline Fulton, 1995 & $\begin{array}{l}\text { Property rights } \\
\text { theory }\end{array}$ & $\begin{array}{l}\text { Technological advancements change the } \\
\text { locus of power in the value chain }\end{array}$ & $\begin{array}{l}\text { The cooperatives' power is } \\
\text { reduced }\end{array}$ \\
\hline Bager, 1996 & Population ecology & $\begin{array}{l}\text { Techno-economic and institutional } \\
\text { changes induce the cooperatives to } \\
\text { imitate other businesses }\end{array}$ & $\begin{array}{l}\text { Conversions, or at least the } \\
\text { loss of a specific co- } \\
\text { operative identity }\end{array}$ \\
\hline $\begin{array}{l}\text { Harte, } \\
1997\end{array}$ & $\begin{array}{l}\text { Transaction cost } \\
\text { and agency theory }\end{array}$ & $\begin{array}{l}\text { Markets are becoming more open, more } \\
\text { transparent, and larger. }\end{array}$ & $\begin{array}{l}\text { Conversions into IOFs or } \\
\text { hybrid forms }\end{array}$ \\
\hline $\begin{array}{l}\text { Holmström, } \\
1999\end{array}$ & $\begin{array}{l}\text { Corporate } \\
\text { governance, capital } \\
\text { markets }\end{array}$ & $\begin{array}{l}\text { As the capital markets function better, } \\
\text { the cooperatives' investment portfolios } \\
\text { become suboptimal. }\end{array}$ & $\begin{array}{l}\text { Traditional cooperative are } \\
\text { increasingly inefficient }\end{array}$ \\
\hline Hogeland, 2006 & $\begin{array}{l}\text { The economic } \\
\text { culture }\end{array}$ & $\begin{array}{l}\text { Industrialization of agriculture, } \\
\text { processing becomes large scale and } \\
\text { capital intensive. }\end{array}$ & $\begin{array}{l}\text { Traditional cooperatives } \\
\text { face difficulties due to } \\
\text { ignorant members }\end{array}$ \\
\hline
\end{tabular}

Source: Jerker Nilsson, Anna Kihlén and Lennart Norell 2009

In 1991 John Kay, a leading British economists, edited a special volume of "Annales de l'économie publique, sociale et cooperative" on demutualization of financial institutions. Without taking into consideration the special social characteristics of cooperatives, he concentrated on the economic dimension only: "It (the article - P.B. \& H.S.) argues that mutual organizations in a commercial environment have the same objective - rent creation - as other firms; they differ in the rule which govern the distribution of the rents which they establish." (p. 479) Of course, what he writes is correct, but it does not provide the whole picture. Kay claimed the whole question of to demutualize or not to be focused on efficiency. This point of view misses the core characteristics of coops: social commitment (besides profits).

In conclusion we can say that demutualization provides solutions for real problems, as hybridization does. The choice between these two options seems to be more a matter of ideology than of efficiency.

So what was - and still is - driving demutualization? In generalizing some suggestions by Roger Buckland and Bernard Thion (1991), we identified three sources which can, but need not, work together: Demutualization is imminent 1) when the traditional incentives for mutual aid on the basis of membership becomes watered down (when the coop has lost its characteristics), 2) when governments provides incentives to demutualize, and 3) when alternative visions of how to improve future prospects become more attractive than the traditional ones. All of that happened especially in the last two decades.

\section{The role of the legal framework}

The institutional contest played a crucial role in drawing the map of demutualization as well as hybridization. As a matter of fact, in many countries the conversion of coops into investor-owned enterprises is not legal. In the EU more that half of the states make it possible for cooperatives to abandon their cooperative status by converting into a commercial company. The countries in which this is possible are: UK, Netherlands, France, Finland, Germany, Spain, and Belgium, and in certain cases also Luxemburg and Denmark. However, in other countries such a move is illegal.

Still a substantial hesitation can be observed: While the UK with $\S 84$ of its "Friendly Societies Act 1974" theoretically enabled de-mutualization, it took 15 more years until the first friendly society set its foot on this path. "Time Assurance Society" thus became "Templeton Life" in 1990 but not during the 1970s (McLean, 1991). A thesis could be that in the UK during the 1970s 
cooperative values were still vivid, but were watered down during the 1980s. Though this thesis need substantiation, the periodization is in time with similar observations presented above, and with the thesis of Americanization in general.

In the USA demutualization provisions vary by state. Some states require approval by state regulatory authorities and the majority of coop-members (in some case the simple majority, in other states the two thirds or the three fourths of the votes), while other states place additional restrictions on the process or expressly prohibit conversion. In 1988, New York ended a 66-year prohibition against demutualization. The Equitable Life Assurance Society, a New York-based mutual and one of the nation's largest life insurers, announced plans in late 1990 to begin the demutualizationprocess. The 1988 New York Statute served as a model for demutualization statutes in other states.

Table 3 Statutory authority for property-casualty insurance company conversions to stock charter

\begin{tabular}{lll}
\hline States that have adopted conversion statutes & & \\
Alabama & Arizona & Arkansas \\
California & Delaware & Florida \\
Georgia & Indiana & Kansas \\
Kentucky & Louisiana & Maine \\
Maryland & Michigan & Minnesota \\
Montana & Nebraska & Nevada \\
New Jersey & New Mexico & New York \\
Ohio & Oklahoma & Pennsylvania \\
South Carolina & South Dakota & Tennessee \\
Utah & Vermont & Virginia \\
Washington & West Virginia & Wisconsin \\
Wyoming & & \\
& & \\
States with no conversion statutes & Connecticut & \\
Colorado & Iowa & District of Columbia \\
Illinois & Missouri & Massachusetts \\
Mississippi & North Dakota & New Hampshire \\
North Carolina & Texas & Oregon \\
Rhode Island & & \\
& & \\
States prohibiting conversions & Hawaii & Idaho \\
Alaska & &
\end{tabular}

Source:Mayer and Smith, 2002

In 1999 Canada encouraged and regulated demutualization by the approval of the Act which permits conversion of mutuals selling their shares to the public. Following this Act, four of the largest mutuals of Canada demutualized. At the same period, Canadian government enacted a law putting many limitations on demutualization.

In 1995 Japan enabled the process of demutualization through the Insurance Business Law and the subsequent amendment of 2000, which further modified the articles in order to solve practical issues associated with the demutualization. It was only after the approval of that amendment that the first demutualization was completed.

However the legal framework played a crucial role not only in allowing or interdicting demutualization, but also by creating an environment that makes demutualization appealing where it is already permitted. Almost everywhere conversions where preceded by institutional innovation, namely the approval of laws reshaping a more competitive framework of the financial or other 
sectors. As Chaddad and Cook claimed in their 2004 contribution, demutualization occurred "after disruptive institutional changes which increase industry rivalry and negatively affect profits." In many cases the same law, which allow mutuals to demutualize, reshaped the competitive environment. The UK Building societies were deregulated in 1986 as a response to a wish for increased competition in the financial services sector. Their US equivalent, the Savings and Loans Associations were deregulated earlier in 1980 after a fall in interest rates left them unable to attract funds (Barnes \& Ward, 1999). In Australia this kind of law was approved in 1992, in Japan in 1995.

In conclusion we could say that de-mutualization usually not only needed a suitable legal framework but was stimulated by it.

\section{Some conclusions}

At the end of the essay two questions remain unsolved. One of our questions asked if demutualization took place in public interest. This brings us back to the topics of efficiency and a proper functioning of the market.

In general, enterprise uses institutional change as a tool of improving efficiency. So we can ask if at the end converted enterprises show a better profitability, higher return for investors and better prices for customers, whatever reasons had driven their demutualization. Until now, the answers have been multifaceted. It is worth quoting some results.

The first affirmative answer was proposed by Masulis 1987, who, after analyzing 205 completed conversions of Saving and Loans Associations between 1974 and 1983, claimed that conversion improved organizational efficiency due to the injection of new equity capital, distribution of managerial stock options, and decreased risk of insolvency.

The 2004 Chaddad and Cook survey of the empirical studies on demutualization in USA suggested ownership structure changed the US insurance industry and was in general efficiencyenhancing. Some years later Lai, McNamara and Tong Yu investigating under-pricing and postconversion long-run stock performance of US-converted mutuals suggested that "there is more "money left on the table" for demutualized insurers than for non-demutualized insurers" (p.1).

In contrast, in 2007 Vivian Jeng, Gene C. Lai and Michael J. McNamara suggested that demutualized US-insurers in the 1980s and 1990s failed to improve efficiency after demutualization, when a value-added approach is used. Some months before, in November 2006, Lal C. Chugh and Joseph W. Meador after examining 11 fully converted former mutuals summarized their study by claiming that long-run market returns of demutualized companies have outperformed various market indexes, including the NASDAQ Insurance Company Index, and had indeed created economic value. According to the authors, management in these companies had successfully implemented a strategy based on higher growth, greater profitability, improved costefficiency, and innovations in product offerings.

Nevertheless this kind of more sophisticated analysis remained confined to USA and Canada and therefore it is difficult to generalize the results. Above all, the evolution of demutualized companies has varied to a great extent in different countries. The worst results have been recorded in the UK where in a decade all the converted building societies lost their independent status either because they were purchased by other banks (Abbey National and Alliance \& Leicester by Bank Santander) or because they failed and were taken into public ownership (Northern Rock and Bradford \& Bingley, Converted 2009).

On the other hand, other authors have challenged exactly such views: Baris Serifsoy, basing his research on 28 stock exchanges, found nothing "to support the view that an outsider-owned exchange enhances the efficiency of the exchange." (p. 329) He explicitly challenged Hart and More, suggesting that the advantages of an IPO of a stock exchange lies mainly with the directly involved personnel of the institution and with a few large financial enterprises to the detriment of the majority of membership, the small local brokers. He thus gave a hint to the role of interests involved (see point C.3). Already in 1991 maintained David Llewellyn and Mark Holmes: 
"...mutuals need not necessarily be any more constrained than public limited companies in achieving objectives related to growth and diversification.”(p. 481).

We can observe there is a mainstream view of economists suggesting indeed inefficiency or lack of growth perspectives of coops, especially in the financial sector. On the other side there is a handful of "diehards" who deny exactly this. For the case of stock exchanges, both sides recently came up with quantitative practical evidence. The authors of this contribution are not in the position to declare one side as winner. Rather we would like to have more practical evidence, also from nonstock exchange financial institutions. How fared the many demutualized insurance and housing societies? One may guess, as with privatization of public ownership, a much better researched topic, the economic results to be mixed.

Several authors, looking for practical evidence for the thesis that demutualization leads to a better performance, presented disappointing results: their findings were at best mixed or the expected improvement simply did not take place. Consequently the few definite winners of such a move were the economic advisers and banks involved, and managers which, now in private business, could ask for higher pay. We conclude: at the business level there are no clear and general advantages from demutualization, beyond the traditional one of shake-ups of any commercial organization.

Besides, in general support of mutuality Llewellyn and Holmes predicted any national sector of finance to be much more stable, when including a substantial part of mutuals: Coops are more tuned to long-term planning and much less risk oriented (1991, 346). Practical evidence during the financial crisis of 2008 showed their prediction to come true in the case of Germany's cooperative Volksbanken. The same is true for savings banks in Germany, who, through their ties to local authorities are also obliged to public welfare. However, the Landesbanken, also obligated, turned out to have been the worst risk-takers or speculators in the whole financial sector. The same applies to the majority of Spanish savings banks. Thus, only financial institutions under tight memberowner control were able to stabilize financial markets. For politicians this provides an argument for not demutualizing financial institutions. So no clear picture emerges that a global demutualization has been efficiency improving and consequently in public interest.

To complete our answer about public interest it would have been useful to take into consideration the impact of demutualization on social capital. Quite surprisingly not a single contribution in our survey has addressed the issue of social capital. We think this should be a necessary part of such accounts, and suggest research to be directed towards this issue.

The last of our questions was about the connection between hybridization and de-mutualization. As we have already mentioned at the beginning of our essay, over the last three decades cooperatives experienced acceleration of institutional innovation with the introduction of many variations to the reference model. It is certainly not surprising that coops changed their organizational structure over time to face the challenges of world economy, as other forms of enterprise did. Therefore hybridization can be considered the coops' answer to the financialization and the globalization processes that had characterized the end of the twentieth century. In spite of the fact that the latter have been a worldwide process, in each country hybridization took on special connotations. In France, Spain and Italy it proceeded quite slowly and was usually accompanied by the definition of new concepts as "social economy", "external mutuality propension", and so on. In other countries, for instances UK and Australia, hybridization took on the appearance of deregulation aiming to mimic key aspects of investor-oriented enterprise and consequently often followed by a complete demutualization of many coops. Still in other countries like Germany the cooperative movement remained tied to past models and there was a different kind of failure that is bankruptcy. Some coops changed too little and lost positions or exit the market, some others changed too much and demutualized. Hybridization could be placed in between these two extremes. In conclusion we could say that demutualization has been the dark side of hybridization. 


\section{List of literature}

All party-Parliamentary group

Amelina, Maria, What turns a kolkhoz into a firm? Regional politics and the elasticity of budget constraints, in: O'Brien, David J. and Wegren, Stephen K. (eds.) Rural reform in Post-Soviet Russia, John Hopkins University Press, Baltimore, 2002, pp. 264-281

Bager, T., Isomorphic processes and the transformation of cooperatives, Annals of Public and Cooperative Economics, January 1994, Volume 65, Issue 1, Pages 35-54.

Barberini, I., Preface, in Battilani P. and Bertagnoni, G., Cooperation, Network, Service: Innovation in outsourcing, Preston, Crucible, 2009

Battilani, P., L'impresa cooperativa in Italia nella seconda metà del Novecento: istituzione marginale o fattore di modernizzazione economica?, Imprese e storia, 2009

Battilani P. and Bertagnoni, G., Cooperation, Network, Service: Innovation in outsourcing, Preston, Crucible, 2009

De Bonis, R. Manzone B. and Trento S. , La proprietà cooperativa: teoria, storia e il caso delle banche popolari in "Temi di discussione del servizio della Banca d'italia", n. 238, 1994

Bekkum, O.F. van, and J. Bijman, Innovations in Cooperative Ownership: Converted and Hybrid Listed Cooperatives, paper presented at the 7th International Conference on Management in AgriFood Chains and Networks, Ede, The Netherlands, 31 May - 2 June, 2006

Birchall, J (1998) 'The Future of Cooperative and Mutual Business', Research and Report, Meiji University,

Buckland, Roger and Bernard Thion, Organizational structure, objectives and agency relationships in banking services: the cases of the Crédit Agricole and trustee savings banks, in: Annales de l'économie publique, sociale et cooperative, 62 (1991), 3, pp. 355-391

Cazzuffi, C. and Hunt D., Causes and consequences of institutional and governance change in cooperative firms: the case of agricultural processing and marketing cooperatives in Italy and in the US, Imprese e storia, 2009

Chandler, Alfred D. Jr., 1990, Scale and Scope, The dynamics of industrial capitalism, Cambridge: Cambridge University Press

Clemens, Richard G., A New Look at Demutualization of Mutual Insurers, Partner, Sidley \& Austin, mimeo

Cronan, Garry, (1995) 'The Conversion Syndrome - A Review of the Conversion of Australian Cooperatives into Investor Owned Firms' Published by the International Cooperative Alliance, Regional Office for the Asia and the Pacific

Cronan, Garry "Something for Nothing - It's Fabulous": An Australian Perspective of Demutualization, 1999, mimeo

Cummins and Venard, Handbooks of international insurance between global dynamics and local contingencies, Springer 2007

Carson J.M., Forster M.D. and McNamara, M.J., 1998, 'Changes in ownership structure: theory and evidence from life insurer demutualizations', Journal of Insurance Issues, 21, 1-22

F. Chaddad and M. Cook, The economics of organization structure changes: an Us perspective on demutualization, Annales de l'économie publique, sociale et coopérative, 75:4 2004 pp. 575-594.

F. Chaddad and M. Cook, Conversion and other forms of exit in Us Agricultural cooperatives, in K. Karantininis and J. Nilsson eds, Vertical markets and cooperative hierarchies. The role of cooperatives in the Agri-food industry, 2007, Springer.

Lal C. Chugh and Joseph W. Meador, Demutualization in the Life Insurance Industry: A Study of Effectiveness, Review of Business Winter 2006 Vol. 27, Number 1 pp 10-17

Chandler, Alfred D. Jr. (1990). Scale and Scope, The dynamics of industrial capitalism, Cambridge: Cambridge University Press

Collins, Robert A., The Conversion of Cooperatives to Publicly Held Corporations:A Financial 
Analysis of Limited Evidence, 1991, Western Journal of Agricultural Economics, 16(2): 326-330. Converting failed financial institutions into mutual organizations. A Report from The Oxford. Centre for Mutual \& Employee-owned Business. Kellogg College, University of Oxford. Published for The Building Societies Association. September 2009

Cook, J, Deakin, S \& Hughes, A (2001) “ Mutuality and Corporate Governance: The Evolution of UK Building Societies Following Deregulation”, Working Paper 205, June 2001, ESCR Center for Business Research, University of Cambridge

Cook, Michael, 1995. The Future of U.S. Agricultural Co-operatives: A Neo-institutional Approach. American Journal of Agricultural Economics, Volume 77, pp. 1153-1159.

Demutualization in Australia, Reserve Bank of Australia Bulletin January 1999

Paul J. Di Maggio and Walter W. Powell, The Iron Cage Revisited: Institutional Isomorphism and Collective Rationality in Organizational FieldsAuthor(s): American Sociological Review, Vol. 48, No. 2, Apr., 1983

Egger, Astrid and Tomanek Peter, Entwicklungsbeiträge von Genossenschaften im Kossovo, in: Rösner, Hans Jürgen and Schulz-Nieswand, Frank (eds.), Beiträge der genossenschaftlichen Selbsthilfe zur wirtschaftlichen und sozialen Entwicklung, Lit Verlag, Berlin, 2009, pp. 543-575.

FAO (ed.) Promoting farmer entrepreneurship through producer organizations in Central and Eastern Europe (prepared by John Millns) Rome, 2006

Fauquet, G., 1951. The Cooperative Sector. The Cooperative Union, Manchester.

Fennell, Mary L. 1980 "The effects of environmental characteristics on the structure of hospital clusters." Administrative Science Quarterly 25:484-510

Fitzgerald, John F., Demutualization case studies: a 20 years history, in: Journal of insurance regulation, Vol. 9, No. 2, Dec. 1990, pp. 287-310.

Fulton, Murray, 1995, The Future of Co-operatives in Canada: A Property Rights Approach. American Journal of Agricultural Economics, Volume 77, pp. 1144-1152.

D. Griffiths, Should our cooperative demutualise? (July 2004) by David Griffiths, from the Australia.coop web portal

Hart, Oliver and John Moore, The governance of exchanges: members' cooperatives versus outside ownership, in: Oxford review of economic policy, 12 (1996), 4, pp. 53-69

Hawley, Amos 1968 "Human ecology." Pp. 328-37 in: David L. Sills (ed.), International Encyclopedia of the Social Sciences. New York: Macmillan

Hetherington J.A.C., 1969, 'Fact vs. fiction: who owns mutual life insurance companies?' Wisconsin Law Review, 4, 1068-1103.

Holstrom, Bengt, Future of Cooperatives:A Corporate Perspective, TLA 4 / 1999

Kay, John A.., The economics of mutuality In: Annales de l'économie publique, sociale et coopérative, Bd. 62 (1991), 3, S.309-318

Keneley, M.J and G. Verhoef, The Decision to Demutualise: An Analysis of the Pressures for Change. The case of life insurers in Australia and South Africa a comparative perspective,

Kramper Peter, NEUE HEIMAT. Unternehmenspolitik und Unternehmensentwicklung im gewerkschaftlichen Wohnungs- und Städtebau 1950-1982, Franz Steiner Verlag, Stuttgart 2008

Kunz, Andreas, Die Akte Neue Heimat. Krise und Abwicklung des größten Wohnungsbaukonzerns Europas 1982-1998, Campus Verlag, Frankfurt 2002

Y. Levi and P. Davis, Cooperatives as the "enfants terribles" of economics: Some implications for the social economy, The Journal of Socio-Economics 37 (2008) 2178-2188

Llewellyn, David T. and Holmes, Mark J., In defence of mutuality: a redress to an emerging conventional wisdom, in: Annales de l'économie publique, sociale et cooperative, 62 (1991), 3, pp. 319-354

Llwellyn D.T., 2004 'Issues in the governance of mutuals in the financial sector', Paper commissioned for the Myners enquiry into Governance of Life Mutuals, London, HM Treasury, UK, available from www.hmtreasury.gov.uk/media/E/C/miners llewellyn.

Masulis R.W., 1987, 'Changes in ownership structure: conversions of mutual savings and loans to 
stock charter', Journal of Financial Economics, 18, 29-59.

Mayers, D. and Clifford. W. Smith., 1986, 'Ownership structure and control: the mutualization of stock life insurance companies', Journal of Financial Economics, 16, 73-98.

Mayers, D., and C. W. Smith, 2002, Ownership Structure and Control: Property-Casualty Insurer Conversions to Stock Charter, Journal of Financial Services Research, 21: 117-144

McLean, Colin, From Time Assurance to Templeton Life: a case study, in: Demutualization of financial institutions, Annales de l'économie publique, sociale et coopérative, Bruxelle, 62 (1991), 3, pp. 455-478

Michael J. McNamara and S. Ghon Rhee, Ownership Structure and Performance: The Demutualization of Life Insurers, The Journal of Risk and Insurance, Vol. 59, No. 2 (Jun., 1992 )

Gene C. Lai, Michael J. McNamara, Tong Yu, The Wealth Effect of Demutualization: Evidence from the U.S. Property-Liability and Life Insurance Industries, 2008

Meyer, John W. 1979 "The impact of the centralization of educational funding and control on state and local organizational governance." Stanford, CA: Institute for Research on Educational Finance and Governance, Stanford University, Program Report No. 79-B20

Jerker Nilsson, Anna Kihlén and Lennart Norell, Are Traditional Cooperatives an Endangered species? About Shrinking Satisfaction, Involvement and Trust, International Food and Agribusiness Management Review Volume 12, Issue 4, 2009

Perks, Robert, The fight to stay mutual: Abbey members against flotation versus Abbey National Building Society, in: Annales de l'économie publique, sociale et coopérative, Vol. 62, No. 3, 1991, pp. 393-429

Serifsoy, Baris, Demutualization, outsider ownership, and stock exchange performance: empirical evidence, in: Economics for Governance, Vol.9, No. 1, 2008, pp. 305-329

Spear, Roger, The Community Interest Company (CIC): a New Form of UK Social Enterprise, mimeo

Schrader L.F., 1989, 'Equity capital and restructuring of cooperatives as investor-oriented firms', Journal of Agricultural Cooperation, 4,41-53.

Schröter, Harm, 2005, Americanization of the European Economy. A compact survey of American economic influence in Europe since the 1880s, Springer, Dordrecht,

Der Verlust der "europäischen Form des Zusammenspiels von Ordnung und Freiheit". Vom

Untergang der deutschen Konsumgenossenschaften, in: Vierteljahrschrift für Sozial- und

Wirtschaftsgeschichte, vol. 87, 2000, No. 4, pp. 442-467

Spiller, R. Ownership and Performance: Stock and Mutual Life Insurance Companies, Journal of

Risk and Insurance 39, 1972, 17-26.

Steding, Rolf and Kramer, Jost W., Konturen der Genossenschaftsentwicklung in den europäischen Transformationsländern, Edition Sigma, Berlin 1998

Stephens, M (2001) "Building Society Demutualization in the UK", Housing Studies, 16 (3) 335-352

G. Tayler, UK building society demutualization motives, Business Ethics: A European Review, Volume 12 Number 4 October 2003.

Treptow, Felix, The economics of demutualization. An Empirical Analysis of the securities exchange industry, Deutscher Universitäts-Verlag, Wiesbaden, 2006

Verbrugge, James A. and Steven Goldstein, 1981. "Risk, Return, and Managerial Objectives: Some Evidence From the Savings and Loan Industry, The Journal of Financial Research 4, pp. 45-58.

Viswanathan, K. S., and J. D. Cummins, 2003, Ownership Structure Changes in the Insurance Industry: An Analysis of Demutualization, Journal of Risk and Insurance, 70: 401-432

Webb (Potter), Batrice (1891): The Cooperative Movement in Great Britain. London, Swan Sonenschein \& Co.; New York, Charles Scribners' Sons

Wegren, Stephen K., Land reform in Russia. Institutional design and behavioural response, Yale University Press, New Haven, 2009. 


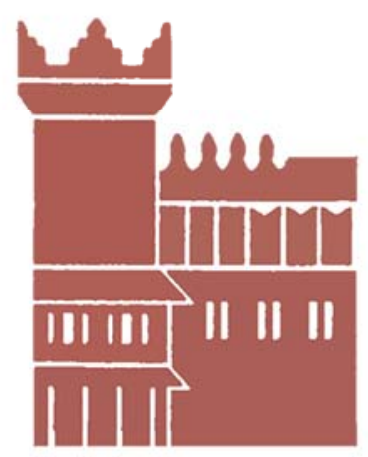

Alma Mater Studiorum - Università di Bologna DEPARTMENT OF ECONOMICS

Strada Maggiore 45

40125 Bologna - Italy

Tel. +39051 2092604

Fax +390512092664

http://www.dse.unibo.it 